RESEARCH PAPER RP1276

Part of Journal of Research of the National Bureau of Standards, Volume 24, February 1940

\title{
REACTION OF BROMINE WITH FURFURAL AND RELATED COMPOUNDS
}

\author{
By Elizabeth E. Hughes and S. F. Acree
}

\section{ABSTRACT}

The mechanism of the reaction of bromine in aqueous solution with furfural and with two related compounds is discussed.

The bromine present and the acidity of the solutions were each determined after various periods of time at $0^{\circ} \mathrm{C}$, to obtain a measure of the bromine consumed, the amount of acid used in liberation of bromine, and the hydrobromic acid generated during the reaction. The product of the reaction of molar proportions of bromine and furfural was precipitated with phenylhydrazine and analyzed. Its composition and the analytical data indicate that when molar proportions of bromine and furfural react, the bromine is changed to bromide ions, 2 equivalents of hydrogen ions are formed from the water, and 2 equivalents of hydroxyl ions or oxygen combine with the furfural.

During a study of the quantitative determination of furfural with bromine, some phases of the mechanism of the reaction were also investigated. The determination depends upon the oxidation of furfural by bromine liberated from a solution of bromate and bromide.

Work by Hill and Sanger [1], ${ }^{1}$ Gilman and Wright [2], and others indicates that in some organic solvents bromine reacts with some furane derivatives by preliminary addition at a double bond, to form a dibromo compound (reactions I and II), which may then be made to lose hydrobromic acid and yield a bromofurane (reaction II). For some unsaturated compounds in water or alcohols, however, it has been shown by Conant and Jackson [3], Dimroth, Schultze, and Heinze [4], Bartlett and Tarbell [5], and others that one hydroxyl or alkoxyl group and one bromine atom may add at a double bond in preference to two atoms of bromine (reaction III). The presumed course of the reaction is indicated as follows:

\footnotetext{
1 Figures in brackets indicate the literature references given at the end of this article.
} 
I. $\mathrm{Br}_{2}+-\mathrm{CH}=\mathrm{CH}-\longrightarrow-\mathrm{CH}^{+}-\mathrm{CH}^{+}-+\mathrm{Br}^{-} \mathrm{Br}^{-} \longrightarrow-\mathrm{CHBr}-\mathrm{CHBr}-$

$\mathrm{HC}-\mathrm{CH} \quad \mathrm{BrHC}-\mathrm{CH}$ 漹 $(-\mathrm{HBr}) \mathrm{HC}-\mathrm{CH}$

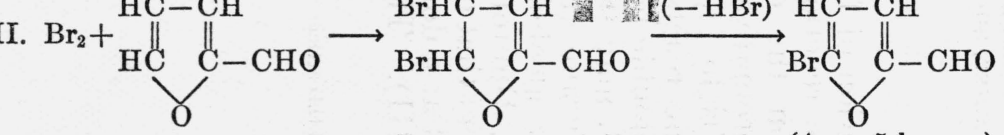

(4- or 5-bromo)

III. $\mathrm{Br}_{2}+\left[\mathrm{H}^{+} \mathrm{OH}^{-}\right]+x \mathrm{Br}^{-}+\underbrace{\mathrm{HC}}_{\mathrm{O}} \|_{-\mathrm{CHO}}^{\mathrm{C}} \longrightarrow \mathrm{HBr}+x \mathrm{Br}^{-}+\underbrace{\mathrm{COHC}}_{\mathrm{O}}$

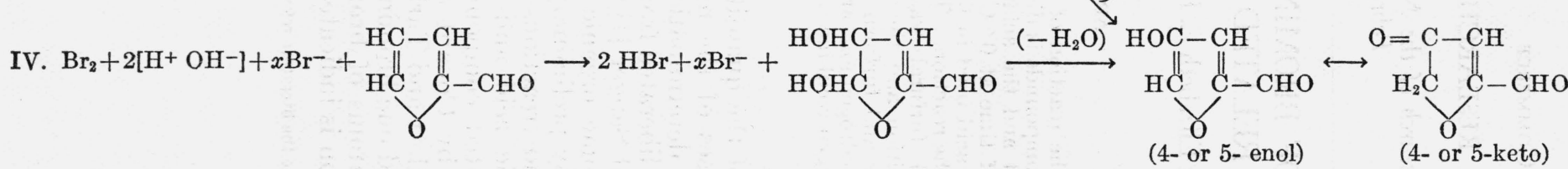

v. $\mathrm{Br}_{2}+2\left[\mathrm{H}^{+} \mathrm{OH}^{-}\right]+x \mathrm{Br}^{-}+\underbrace{\mathrm{HC}}_{\mathrm{O}}\|_{\mathrm{C}}^{\mathrm{HCHO}}-\mathrm{CHO} \mathrm{HBr}+x \mathrm{Br}^{-}+\mathrm{H}_{2} \mathrm{O}+\underbrace{\mathrm{CH}}_{\mathrm{O}}\|_{\|}^{\mathrm{CH}}-\mathrm{COOH}$ 
The course of the reaction is determined by the dielectric constant of the solvent through its influence on the electronic exchanges which take place. There exists also the possibility of the addition of two hydroxyl groups at a double bond (reaction IV), or of oxidation of the aldehyde group to carboxyl (reaction V). Additions of $\mathrm{OH}^{-}$and $\mathrm{Br}^{-}$at the 4,5 positions are assumed in the above reactions merely for convenient representation. The structure was not determined, and substitution or addition may occur at other positions.

Data on the change in acidity during the reactions and information on the end products formed may differentiate between the various possibilities. In reaction II and in III, 1 equivalent of hydrobromic acid is formed; in IV or a sequence of III and IV as shown, 2 equivalents of hydrobromic acid are formed; and in V, 2 equivalents of hydrobromic acid and one carboxyl group, or 3 equivalents of acid, are formed. In this work there was no attempt to distinguish between the reactions of the 2,3 and 4,5 double bonds of furfural compounds or of their conjugated 2,5- systems.

In the experiments bromine was liberated at $0^{\circ} \mathrm{C}$ from $25 \mathrm{ml}$ of a solution of $0.1 \mathrm{~N}$ potassium bromate-bromide by an equivalent amount of hydrobromic acid in the presence of molar equivalents of the reducing substance. As 2 equivalents of hydrobromic acid are slowly used up to liberate 1 mole of bromine according to the equation

$$
\mathrm{KBrO}_{3}+6 \mathrm{H}^{+}+6 \mathrm{Br}^{-} \rightarrow \mathrm{KBr}+3 \mathrm{H}_{2} \mathrm{O}+3 \mathrm{Br}_{2},
$$

individual experiments were performed for different periods of time from 1 hour through several hours or days. Under these conditions, when 1 mole of bromine reacts with 1 mole of furfural, methylfurfural, or furoic acid there is no bromine color apparent at any time. This indicates that the bromine is consumed as soon as it is liberated.

In each experiment the acid was first titrated with $0.1 \mathrm{~N}$ solution of sodium hydroxide, using phenolphthalein as the indicator, and the remaining bromate was then determined iodometrically after the addition of potassium iodide and concentrated hydrochloric acid. With known amounts of acid and of available bromine present at the beginning of the reaction, one may calculate the bromine consumed, which is liberated by an equivalent amount of acid, and the amount of acid regenerated. The figures in tables 1 and 3 show that in the cases of furfural and of furoic acid there is no decrease in acidity at any time during the reaction. The data for methylfurfural in table 2 show that more than 2 equivalents of acid are formed per mole of bromine consumed.

In considering the mechanism of the reaction of 1 mole of bromine with these compounds, the following conclusions may be tentatively drawn. The above experiments on acidity point to reaction IV or the sequence III to IV, in both of which 2 equivalents of hydrobromic acid are regenerated. The data for furfural exclude reaction II, in which 1 mole of acid is formed; the first and second steps in reaction III, in which 1 equivalent of hydrobromic acid is formed; and reaction $\mathrm{V}$, in which 3 equivalents of acid are formed. The decided increase in acid content with methylfurfural indicates the formation of methylfuroic or other acid. In the case of furoic acid, the end point was not permanent. The figures in parentheses in the third column of table 
3 indicate the amount of alkali required to maintain the end point after it was first reached. This alkali was probably consumed in neutralization of hydrobromic acid or of a keto-lactone formed in secondary steps, as in II or III. In view of the general stability of bromohydrins, and the fact that some further experiments not reported here showed that a monobromo compound is formed when furfural reacts with 2 moles of bromine under these conditions, reaction IV is preferred.

TABLE 1.-Reaction of 1 mole of bromine with furfural in $0.1 \mathrm{~N}$ hydrobromic acid at $0^{\circ} \mathrm{C}$

\begin{tabular}{|c|c|c|c|c|}
\hline \multicolumn{3}{|c|}{ Present at start of reaction } & \multirow{4}{*}{$\begin{array}{l}\text { Acid } \\
\text { con• } \\
\text { sumed }\end{array}$} & \multirow{4}{*}{$\begin{array}{l}\text { Acid } \\
\text { regen- } \\
\text { erated }\end{array}$} \\
\hline $\begin{array}{l}\text { Milligrams of furfural, } \\
\qquad 120.0\end{array}$ & $\begin{array}{c}\text { Milliequiv- } \\
\text { alents of } \\
\mathrm{KBr}-\mathrm{KBrO}_{3} \\
2.492\end{array}$ & $\begin{array}{l}\text { Milliequiv- } \\
\text { alents of } \\
\mathrm{HBr} \text {, } \\
2.546\end{array}$ & & \\
\hline \multicolumn{3}{|c|}{ Experimental data } & & \\
\hline Period of reaction & $\mathrm{Na}_{9} \mathrm{~S}_{9} \mathrm{O}_{8}$ used & $\mathrm{NaOH}$ used & & \\
\hline 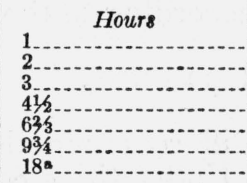 & $\begin{array}{l}M-e q \\
2.124 \\
1.830 \\
1.480 \\
1.240 \\
0.716 \\
.517 \\
.000\end{array}$ & $\begin{array}{l}M-e q \\
2.542 \\
2.542 \\
2.542 \\
2.542 \\
2.546 \\
2.548 \\
2.544\end{array}$ & $\begin{array}{l}M-e q \\
0.368 \\
.662 \\
1.012 \\
1.252 \\
1.776 \\
1.975 \\
2.492\end{array}$ & $\begin{array}{l}M-e q \\
0.364 \\
.658 \\
1.008 \\
1.248 \\
1.776 \\
1.977 \\
2.490\end{array}$ \\
\hline
\end{tabular}

- A temperature of $0^{\circ} \pm 2^{\circ} \mathrm{C}$ was maintained in these experiments by use of an ice bath. In the experiment of 18 hours, the ice melted in the bath overnight with \& resulting temperature slightly higher toward the end of the reaction.

TABLE 2.-Reaction of 1 mole of bromine with methylfurfural in $0.1 \mathrm{~N}$ hydrobromic acid at $0^{\circ} \mathrm{C}$

\begin{tabular}{|c|c|c|c|c|}
\hline \multicolumn{3}{|c|}{ Present at start of reaction } & \multirow{4}{*}{$\begin{array}{l}\text { Acid con- } \\
\text { sumed }\end{array}$} & \multirow{4}{*}{$\begin{array}{l}\text { Acid re } \\
\text { generated }\end{array}$} \\
\hline $\begin{array}{c}\text { Milligrams of } \\
\text { methylfurfural, } \\
137.0\end{array}$ & $\begin{array}{c}\text { Milliequivs- } \\
\text { lents of } \\
\mathrm{KBr}^{\mathrm{KBBrO}}, \\
2.493\end{array}$ & $\begin{array}{c}\text { Milliequiva- } \\
\text { lents of } \mathrm{HBr} \text {, } \\
2.546\end{array}$ & & \\
\hline \multicolumn{3}{|c|}{ Experimental data } & & \\
\hline Period of reaction & $\mathrm{Na}_{2} \mathrm{~S}_{2} \mathrm{O}_{8}$ used & $\mathrm{NaOH}$ used & & \\
\hline $\begin{array}{l}1 \mathrm{hr} \\
2 \mathrm{hr} \\
3 \mathrm{hr} \\
4 \mathrm{hr} \\
716 \mathrm{hr} \\
12 \mathrm{hr} \\
18 \mathrm{hr}\end{array}$ & $\begin{array}{l}M-e q \\
2.170 \\
1.877 \\
1.667 \\
1.554 \\
0.962 \\
.570 \\
.063 \\
.000\end{array}$ & $\begin{array}{l}M-e q \\
2.550 \\
2.560 \\
2.562 \\
2.562 \\
2.689 \\
2.931 \\
3.143 \\
3.169\end{array}$ & $\begin{array}{l}M-e q \\
0.323 \\
.616 \\
.826 \\
.939 \\
1.531 \\
1.923 \\
2.430 \\
2.493\end{array}$ & $\begin{array}{r}M-e q \\
0.327 \\
.630 \\
.842 \\
.955 \\
1.674 \\
2.308 \\
3.027 \\
3.116\end{array}$ \\
\hline
\end{tabular}


TABLE 3.-Reaction of 1 mole of bromine with furoic acid in $0.1 \mathrm{~N}$ hydrobromic acid at $0^{\circ} \mathrm{C}$

\begin{tabular}{|c|c|c|c|c|}
\hline \multicolumn{3}{|c|}{ Present at start of reaction } & \multirow{5}{*}{$\begin{array}{l}\text { Acid con- } \\
\text { sumed }\end{array}$} & \multirow{5}{*}{$\begin{array}{l}\text { Acid re- } \\
\text { generated }\end{array}$} \\
\hline $\begin{array}{l}\text { Milligrams of } \\
\text { furoic acid, }\end{array}$ & $\begin{array}{c}\text { Milliequiva- } \\
\text { alents of } \\
\mathrm{KBr}-\mathrm{KBrO}\end{array}$ & $\begin{array}{l}\text { Milliequiv- } \\
\text { alents of } \\
\text { HBr } \\
\text { Furoic acid. } 1.2503\end{array}$ & & \\
\hline 140.0 & 2.546 & 3. 758 & & \\
\hline \multicolumn{3}{|c|}{ Experimental data } & & \\
\hline Period of reaction & $\mathrm{Na}_{9} \mathrm{~S}_{3} \mathrm{O}_{3}$ used & $\mathrm{NaOH}$ used & & \\
\hline $\begin{array}{l}5 \mathrm{~min} \\
1 \mathrm{hr} \\
2 \mathrm{hr} \\
\mathbf{4 h r} \\
6 \mathrm{hr} \\
17 \mathrm{hr} \\
10 \text { days. } \\
11 \text { days. }\end{array}$ & $\begin{array}{r}M-e q \\
2.481 \\
1.988 \\
1.424 \\
1.034 \\
0.583 \\
.038 \\
.000 \\
.000\end{array}$ & $\begin{array}{l}\text { M-eq } \\
\text { 3. } 743 \\
\text { 3. } 651 \\
\text { 3. } 557(0.192)= \\
\text { 3. } 472(.387) \\
\text { 3. } 436(.466) \\
\text { 3. } 390(.519) \\
\text { 3. } 687 \\
\text { 3. } 696\end{array}$ & $\begin{array}{c}M-e q \\
0.065 \\
.558 \\
1.122 \\
1.512 \\
1.963 \\
2.508 \\
2.546 \\
2.546\end{array}$ & $\begin{array}{r}M-e q \\
0.050 \\
.451 \\
.921 \\
1.226 \\
1.641 \\
2.140 \\
2.475 \\
2.484\end{array}$ \\
\hline
\end{tabular}

- Figures in parentheses represent additional amounts of alkali slowly added after the first figure was obtained for the end point. Column 5 does not include these figures.

Attempts to isolate the product of the reaction of 1 mole of bromine with 1 mole of furfural in such dilute solutions by means of extraction or steam distillation were unsuccessful. However, a precipitate is immediately formed when phenylhydrazine in acetic acid solution is added to the reaction product at $0^{\circ} \mathrm{C}$. The compound crystallizes from alcohol and water as plates, which melt at $155^{\circ} \mathrm{C}$. It contains no bromine, which confirms the conclusions from the acidity data. The elementary analysis ${ }^{2}$ shows that instead of the phenylhydrazone of a dihydroxydihydrofurfural which might be expected, a dihydrazone of a hydroxy or ketodihydrofurfural is obtained. This could occur by loss of water and rearrangement as shown in reaction IV. Since the precipitation at this low temperature is immediate, it seems likely that there are two carbonyl groups ready to react with the phenylhydrazine.

Dihydrazone of a ketodihydrofurfural, $\mathrm{C}_{17} \mathrm{H}_{16} \mathrm{~N}_{1} \mathrm{O}$ (molecular weight 292).

Calculated: C, $69.8 \%$; H, $5.5 \%$; N $19.2 \%$; O, $5.5 \%$.

Found: $\mathrm{C}, 69.2 \% ; \mathrm{H}, 6.0 \% ; \mathrm{N}, 18.9 \% ; \mathrm{O}, 5.9 \%$ (by difference). A phenylhydrazone of a dihydroxydihydrofurfural, $\mathrm{C}_{11} \mathrm{H}_{12} \mathrm{~N}_{2} \mathrm{O}_{3}$, would have the following composition: $\mathrm{C}, 60.0 \% ; \mathrm{H}, 5.5 \%$; and $\mathrm{N}, 12.7 \%$. This clearly does not correspond to the compound that was obtained.

The evidence above indicates that the reaction consists in the addition of two hydroxyl ions to a positive double bond and the formation of 2 equivalents of hydrobromic acid, as in reaction IV. In this reaction the same electronic transfers as those illustrated in reaction I may take place, except that hydroxyl ions rather than bromide ions join the positive double bond. This interpretation harmonizes with the explanation given by Myers, Clarke, and Acree [6] for the electromotive force observed between ethylene and chlorine electrodes.

This analysis was kindly made by C. J. Rodden, of the National Bureau of Standards. 
The reaction at $0^{\circ} \mathrm{C}$ of equimolar quantities of furfural and bromine in water was studied. At all stages during the reaction, the experimental evidence indicates that the bromine consumed was converted quantitatively to hydrobromic acid. The product of the reaction was a hydroxy or ketodihydrofurfural, the bisphenylhydrazone of which was isolated and analyzed. With minor side reactions, methylfurfural and furoic acid behave in the same general way as furfural.

[1] H. B. Hill and C. R. Sanger, Liebigs Ann. Chem. 232, 42 (1885).

[2] H. Gilman and G. F. Wright, J. Am. Chem. Soc. 52, 3349 (1930).

[3] J. B. Conant and E. L. Jackson, J. Am. Chem. Soc. 46, 1727 (1924).

[4] O. Dimroth, E. Schultze, and F. Heinze, Ber. deut. chem. Ges. 54, 3035 (1921).

[5] P. D. Bartlett and D. S. Tarbell, J. Am. Chem. Soc. 58, 466 (1936).

[6] C. N. Myers, W. F. Clarke, and S. F. Acree, Phys. Chem. 20, 286 (1916).

Washington, December 5, 1939. 